\title{
Slavko Gaber and Veronika Tašner (Eds.), The Future of School in the Societies of Work without Work [In Slovene: Prihodnost šole v družbah dela brez dela], Faculty of Education: Ljubljana, 2017; 207 pp.: ISBN: 978-961-253- 204-8
}

Reviewed by Matjaž PolJANŠEK ${ }^{1}$

There has been an increase in the amount of news and the number of commentaries in the media about the rapid digitalisation and robotisation of (post)modern societies. Typically, these commentaries do not go beyond general findings and projections about the number of jobs lost in various fields, even those fields where human labour was regarded as irreplaceable until recently. We can only welcome such media reports, for it seems that not even minimum social consideration has been given to a phenomenon that is not just around the corner, but is here. Naturally, these reports lack suitable concep-

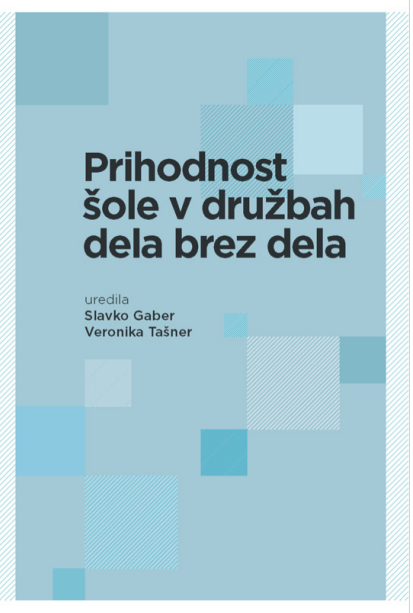
tualisation and theorisation, without which the phenomenon cannot be seriously deliberated, monitored, reacted to and directed. Fortunately, literature has started to emerge that reacts more appropriately to the need for a more indepth analysis of technological change and its social implications. A small but important part thereof is the collection of scientific papers entitled The Future of School in Societies of Work without Work, whose value is evident in the fact that it deals seriously with (but not only with) the role of school in the processes of the rapid digitalisation and robotisation of society.

The collection consists of nine papers. In the first, entitled Time of Alternation?, authors Veronika Tašner and Slavko Gaber establish that it does not seem that we will see the end of work, but that this does not mean Fordian-type wage labour will retain the status it has at the moment. Evidently, it is becoming less stable and durable, with individuals facing perpetual demands that they upgrade their competences and skills. Since technological progress promises a

$1 \quad$ Gimnazija Vič, Slovenia; matjaz.poljansek@guest.arnes.si. 
radical loss of jobs, a new relation between wage labour, capital and the state will be required. Wage labourers are increasingly becoming citizens, and in future their rights will stem more from their citizenship than from their employment status. Citizenship will be the basis for eligibility for basic social goods. It will be interesting to watch the reaction of the public to this necessity, as society at large still holds the deeply rooted view that "he who does not work, neither shall he eat". This has been evident in the debate on the potential introduction of a universal basic income.

In the second paper, entitled Work and School, Veronika Tašner provides a historical overview of the development of school as a social institution and highlights the school-work relationship. While school (scholé) in ancient Greek meant leisure and was associated with fun, play and free time, it became at one point associated with social production processes of ideological homogenisation and economic efficiency. Children at school are given a reprieve from entering the adult world, but school has become a space of heteronomous work, school work. School has become mandatory and classes must be attended regardless of students' enjoyment thereof. School transfers knowledge and skills, it enhances obedience, order and discipline, and increases the student's intellectual potential. For the individual, knowledge brings value, power and employability, and is thus an instrument of survival. The historical overview of the establishment, development and functions of school systems is necessary when deliberating about school and its role in the future. The paper is thus logically placed at the beginning of the collection.

In the third paper, Slavko Gaber re-actualises John Dewey, who, at a time of rapid industrial growth and the prominent instrumentation of knowledge, mainly gave school a formative role, viewing it as the inception of society. Dewey highlights the integrational role of school as society's inception and believes that school is too focused on intellectual aspects of human nature and omits the human tendency to produce something, to create something useful or aesthetic. In so doing, the student develops ingenuity, patience, diligence, perseverance and discipline, and becomes familiar with various materials. In addition, school must execute lessons that facilitate an understanding of social life. It helps form the spectrum of values common to citizens. The highest goal of education is education itself. This exceeds the instrumentation of school. It seems that Dewey's vision of school from the beginning of the twentieth century will be all the more topical as the twenty-first century unfolds, as it has become clear that school in the basic production sense of transferring instrumental knowledge is becoming an anachronism.

Christian Laval highlights two issues that contemporary society must address in Two Education Crises. The first is tied to equal opportunities in 
education and the second to intergenerational relations, which raise the question of reciprocity. In the first case, Laval keeps to his line from Lescola no és una empresa (The School Is Not a Company), in which he radically criticises the neoliberal marketisation of education. Not only does it prevent the implementation of many social (political) interventions that would improve the chances of the successful education of children from families of lower socioeconomic standing, it also drives the economics of knowledge, meaning that knowledge serves the competitiveness of the economy above all else and is a service that answers to individual demand. School is no longer an institution that is capable of thinking, establishing and changing society. Laval stresses that school's basic task is centred on producing human capital, and that this transformation, which seems technically, organisationally and semantically neutral, is in fact deeply political. The striving for economic efficiency supersedes the will for intellectual emancipation. At one point, Laval moves away from the position taken in Lescola no és una empresa and claims that these changes are not so much a consequence of pressure from business and the liberal-inspired right as they are a consequence of a wider social development: of the utilitarian notion about institutions as the "instruments of welfare". He lists several education policies that are required for a path towards increased equal opportunities. At the same time, he clearly states that this will not happen without broader policies in favour of social equality.

Laval believes that the second crisis is generational, as seen in the inability of young people to enter the labour market and in the increase in legislative and pay inequality. Young people are the first victims of the weakening of social bonds and are losing their attachment to the collective world, which is accompanied by a sense of uselessness and rootlessness, a sense of existing without an acknowledged place. This is an opportune place to highlight the somewhat surprising findings in the latest surveys among young people (Eurobaromoeter), which suggest that young people have never before expressed such satisfaction with life and have never before been as optimistic about their future as they are now. Social psychologist Mirjana Nastaran Ule, who says that young people were the most pessimistic generation in the 1980s, believes that the current optimism stems from the plurality of their life worlds. Youths have shifted their values and exchanged material and career values for those more accessible in the given circumstances, and have connected to their sense of accomplishment through social activities, sports and leisure. Young people live on their own "islands of happiness", which means that they are less responsive to current social challenges that politicians should address. This isolation of social groups is also discussed by Laval, who believes that the disappearance of intergenerational 
solidarity stems from the disappearance of the reciprocal duty between generations. He refers to Marcel Mauss and his The Gift, from which he concludes that it is not necessary to return symbolic goods to those from whom we received them; we can pass them on to another group, which transfers them to yet another group. The direct return of that which we have received from our parents would erase the debt but endanger the existence of the bonds between generations. Laval believes that the deregulation of intergenerational relations stems from the materialisation of social life. This is seen in the equalisation of social relations with contractual relations, which are guided by the benefits of the individual contracting parties. The relation of mutual duty, which binds together different generations, is becoming weaker and subsequently isolates groups. The privatisation of life leads to the isolation of generations, and the absence of the past leads to an obscuring of the future.

In Les temps nouveaux de l'education (New Education Times) Roger Sue takes a critical approach to contemporary school, which, according to him, has not changed much since the times of industrial labour. The form of education that highlights order and discipline, and knowledge to a lesser degree, completely suited industrial labour. We can agree with the author that an individual establishes him/herself more and more through the multitude of his/her social roles and practices outside work, especially through the exceptional scope of communication, socialisation and assembly practices. However, we find it difficult to agree with the statement that school is poor at preparing for that which is already a fundamental element of a life. Statements about the utter uniformity of school work do not withstand empirical testing of the school quotidian. It is also difficult to agree with the statement that success in school depends more than ever on the quality of private extracurricular, individual or family activities, that school is only a space of formal reproduction that occurs outside of school. It is true that the socioeconomic status of the student's family is still relevant, but this influence can be reduced fundamentally with suitable interventions inside and outside school. In fact, the opposite is true: in countries that have undertaken to reduce the impact of socioeconomic background on the educational success of children with comprehensive policies, this impact is the smallest it has ever been. Of course, we must immediately highlight the necessity to carefully monitor these effects in the future. In the event of a shortening of working hours, a potential transfer of functions of socialisation (education) back to the family could prove to be a path towards a more radical class reproduction precisely through the reproduction of familial cultural capital.

In the paper Economic Possibilities for Our Grandchildren, John Maynard Keynes once again demonstrates his exceptional intellectual insight and 
sketches the outlines of the economy of the future. Keynes wrote the article in 1930. He wondered about the rational expectations regarding economic life in a hundred years. He rejected the pessimism of revolutionaries who thought that everything was bad and that only a violent revolution could lead to positive change. At the same time, he rejected the pessimism of reactionaries who believed that the balance of economic and social life of the time was so fragile that risking any change would be too dangerous. Keynes believed that the economic problem of humanity would be solved within the next hundred years, and if not, a solution would at least be on the horizon. This would make it possible to use the energy for noneconomic goals, and mankind would be faced with the question of how people should spend time to live their lives in a wise, agreeable and good way for the first time in history. The behaviour of the wealthy classes of the time did not fill him with optimism about the abundance of free time being spent in a quality way. Numerous experimental introductions of a universal basic income will shortly reveal what people will do with more free time. Two things will probably happen: more time will be spent in front of TV and, at the same time, more time will be spent significantly more productively and usefully. Further deliberations deal with the balance between the two in various social groups and categories, and with the extent to which this balance could be regulated.

What happens if robots take the jobs? Darrel M. West wonders in Chapter 9 and lists a number of areas of work where robots are increasingly ascendant. Today, robots are a feasible alternative to wage labour. This creates a number of problems, as social rights are to a large extent tied to employment. West proposes the introduction of a UBI, activity accounts for lifetime education and retraining, expansion of corporate profit-sharing, the introduction of benefit credits for worthy volunteering, etc. West also touches on school and admonishes in particular primary school, which is still quite good at producing the workers we have needed until recently: basic skills, the ability to follow instructions, executing defined tasks with some level of consistency and reliability. Now, we need people who can negotiate, provide loving and compassionate care, motivate a team of people, design a great experience, realise what people want or need, and determine and solve the next problem. The diversity of didactic approaches and the general dynamic of pedagogic work in schools do not corroborate these statements, but it is true that the focus will shift towards creative dimensions of education in the future. However, we must not forget the function of school as a factor in informal socialisation and the creator of collective consciousness. This can only be done in a tested way by the good old school as discussed by Durkheim. 
Especially interesting and important, as its corresponds most substantively to the title of the collection of papers, is the last part, Outlines of the Problematics of the Future of Contemporary Societies and School, in which Slavko Gaber, Ljubica Marjanovič Umek and Veronika Tašner discuss potential and possible - not really sensible and necessary - education policies of the coming decades. In contrast to the dominant discourse, they stress that the generations that are entering the labour market will not work to the age of 67 or even 70 . People will probably be employed and active at that age, but not in wage labour and, if they are, they will work significantly shorter work hours. Trade unions' activities will not play a crucial role in this; technological change will. Meritocratic logic will no longer apply because the universalisation of tertiary education produces highly educated people who have the knowledge and the will to work, but the labour market does not accept them. In this respect, individual responsibility is being reduced. A new paradigm of coexistence will have to be sought, and thus a new paradigm of production and the distribution of the goods necessary for a suitable life. This change will also affect the content, organisation, time and mode of operation of school. The authors also believe that parents, who in the past did not have enough knowledge and time to help children learn, will be able to take on a part of the tasks that are performed by school today. Consequently, the need for after-school facilities will be reduced. Children will come to school with different kinds of new knowledge, obtained through more intense family contact and other social environments. As we have said before, this will undoubtedly increase the influence of the family's cultural capital and exacerbate inequality stemming from social background. Kindergartens, schools and other social institutions will have to be especially attentive to this.

Naturally, this phase of scientific deliberations on the role and mode of school operation is about raising questions and carefully outlining multiple possible answers. The authors have certainly succeeded: What part of education should be dedicated to professional training and what part to general education? How important will education be without mainly serving professional training and preparation for wage labour? What are schools supposed to do if they prepare children for "life", which is spending time outside the work sphere? How will we divide these two spheres and where will they stay connected? The authors do not romanticise the future and do not speak a utopian language; instead, they say that wage labour will not disappear and thus nor will its instrumental role. Complex knowledge will remain necessary in the future if we want to perform certain work or engage in a particular profession. Despite everything, school will remain the space of systemic teaching, organisation, 
transfer and evaluation of knowledge. It will also be a space of convergence of knowledge obtained from other sources, a space of the confrontation, systematisation and evaluation of knowledge. School will remain the space of seeking and critical evaluation, but its emphasis on profession surely will be reduced.

What is particularly intriguing is that the authors see school as needing to move towards the centre of the collective. Clearly, there are numerous challenges ahead, probably for all social subsystems. The question is whether school will be able to carry this out and whether it will even be allowed to do so.

The present collection of papers is an important and valuable contribution to the much needed deliberations on school in the society of the future. It is high time to accelerate serious and systematic studies of the topic, despite the fact that we in Slovenia, as in many other societies that deal with rapid demographic change, will face (despite high levels of structural unemployment) more problems due to a shortage of workers than a shortage of work in the coming years. 